University of Wollongong

Research Online

Faculty of Law - Papers (Archive)

Faculty of Business and Law

$1-9-2006$

\title{
Living Legal Fictions: Constituting the State or Submerging the Signifier
}

Richard Mohr

University of Wollongong, rmohr@uow.edu.au

Follow this and additional works at: https://ro.uow.edu.au/lawpapers

Part of the Law Commons

\section{Recommended Citation}

Mohr, Richard: Living Legal Fictions: Constituting the State or Submerging the Signifier 2006.

https://ro.uow.edu.au/lawpapers/12

Research Online is the open access institutional repository for the University of Wollongong. For further information contact the UOW Library: research-pubs@uow.edu.au 


\title{
Living Legal Fictions: Constituting the State or Submerging the Signifier
}

\begin{abstract}
This is an inquiry into the ways the state is constituted as an effective legal fiction. It is based on the premise that the state was not constituted, once and for all, some three centuries ago (as Bourdieu suggests) but that the existence of the state relies on continuing legal and social processes. The focus is on the translation from the legal to the social, specifically the semiotic interaction between law, space and daily life in the dynamics of this on-going mise en scène. This requires re-thinking a number of semiotic issues: first, Lefebvre's challenge to a semiotics which neglects the place of the material (body, space) and, second, a challenge to Lefebvre's assertions that the state operates in a realm of freedom in switching 'at will' between codes. Third, it is possible to question the conditions by which the state operates as a 'floating signifier' which maintains its domination by overwhelming us with its excess meanings. The inquiry proceeds by analysing the legal semiotics of space in different settings: the axis as an expression of legal and state power, from the courtroom to the capital city (Rome, Washington, Canberra), and street names with legal referents (Montréal and Mexico City, in addition to the above). After considering these self conscious attempts at meaning-making, the article concludes that the legal constitution of the state in urban space is not determined by a single wilful semiotic regime, but (taking insights from de Certeau) is contingent upon the interpretations and enactments of people who use the spaces. Except in the controlled environments of the courtroom and the planned capital city, everyday life is continually reconstituting the meanings of law and the state.
\end{abstract}

\section{Disciplines}

Law

\section{Publication Details}

This article was originally published as Mohr, R, Living Legal Fictions: Constituting the State or Submerging the Signifier, International Journal for the Semiotics of Law, 19, 2006, 237-258. Copyright Springer. Original article available here. 


\title{
Living Legal Fictions: Constituting the State or Submerging the Signifier?
}

International Journal for the Semiotics of Law (2006) 19: 237-258

The original publication is available at www.springerlink.com

< http://dx.doi.org/10.1007/s11196-006-9021-1>

\section{Richard Mohr ${ }^{*}$}

\begin{abstract}
This is an inquiry into the ways the state is constituted as an effective legal fiction. It is based on the premise that the state was not constituted, once and for all, some three centuries ago (as Bourdieu suggests) but that the existence of the state relies on continuing legal and social processes. The focus is on the translation from the legal to the social, specifically the semiotic interaction between law, space and daily life in the dynamics of this on-going mise en scène. This requires re-thinking a number of semiotic issues: first, Lefebvre's challenge to a semiotics which neglects the place of the material (body, space) and, second, a challenge to Lefebvre's assertions that the state operates in a realm of freedom in switching 'at will' between codes. Third, it is possible to question the conditions by which the state operates as a 'floating signifier' which maintains its domination by overwhelming us with its excess meanings.
\end{abstract}

The inquiry proceeds by analysing the legal semiotics of space in different settings: the axis as an expression of legal and state power, from the courtroom to the capital city (Rome, Washington, Canberra), and street names with legal referents (Montréal and Mexico City, in addition to the above). After considering these self conscious attempts at meaning-making, the article concludes that the legal constitution of the state in urban space is not determined by a single wilful semiotic regime, but (taking insights from de Certeau) is contingent upon the interpretations and enactments of people who use the spaces. Except in the controlled environments of the courtroom and the planned capital city, everyday life is continually reconstituting the meanings of law and the state.

\section{Constituting the state}

The relationship between law and the state is a key problem for legal semiotics which may be approached by questioning the influence, constraining and supportive, of law upon the state. Law constrains the state to conform to the rule

\footnotetext{
Faculty of Law, University of Wollongong NSW 2522 rick_mohr@uow.edu.au
} 
of law, to be an "Empire of laws and not of men"1, in the classical English formula. On the other hand, the law plays a central role in creating the state as a fictio legis. Let me sketch some dimensions to either of these approaches from a semiotic point of view before introducing the more limited scope of the present inquiry.

To represent the law as ruling over the state, without human intervention ("not of men"), requires a semiotic manoeuvre of some intricacy. The law must be seen to have greater power or authority than the state, despite the fact that the legislature which passes the laws, and the courts which determine their application, are both arms of state power. They rely on state revenue and on other state institutions-electoral commissions, police, executive departments, infrastructure development and maintenance, parliamentary and judicial staff-to sustain all their activities. Add to this the fact that the legislatures and courts are composed of women and men who do the legislating and the determining. That each of these facts is quite obvious and widely accepted, side by side with a widespread faith in the rule of law, to which we hear constant appeals and references, generally in good faith, indicates something of a triumph for legal semiotics. Law is successfully represented as independent of the individuals who administer it, and as having an independent authority over the institutions upon which it relies for its sustenance.

On the other hand, the state has been seen as a creature of law. Bourdieu sees the role of the law in constituting the state as part of a web of accumulation of 'symbolic capital', with the state at the centre. While various forms of symbolic capital accumulate in military, financial and legal fields, he sees the state as the central force in unifying and exercising symbolic power. ${ }^{2}$ The fundamental importance of the law may be seen in the fact that the state is first constructed as a fictio legis, while subsequently attaining autonomy and its own independent power. $^{3}$

This transition from legal fiction to autonomous power raises the question, how has the situation changed? In each of Bourdieu's descriptions of the state's increased autonomy in the essay "Rethinking the State", we find the state itself as the protagonist. There are two problems with this account, the first being the inherent difficulty of lifting oneself up by one's own shoe strings. If the 'state' was a fiction how did it actualise 'itself'? The second problem is that Bourdieu's account suggests that the state, once created as a fiction of law, takes on a concrete reality over time. Is it not more helpful to understand that this creation is

\footnotetext{
${ }^{1}$ Harrington, 1656, quoted Fred Dallmayr, "Hermeneutics and the Rule of Law", in Deconstruction and the Possibility of Justice, ed. Drucilla Cornell, Michel Rosenfeld and David Gray Carlson. (New York \& London: Routledge, 1992), 283-304 at 286.

2 Pierre Bourdieu, Practical Reason: On the Theory of Action (Stanford, CA: Stanford University Press, 1998), 47.

${ }^{3}$ Supra n. 2 at 58.
} 
a continuous process, and to agree with Correas that "[t]his is the principal function of the law: the creation of the fictional entity called the state". 4

From a survey of sociological and Marxist theories of the state Abrams concluded that the state only exists as a "collective (mis)representation" which "never emerges except as a claim to domination". ${ }^{5}$ It is nevertheless treated as an entity, a noun rather than a verb, despite the lack of any agreed or perceptible "natural fact" in which we can discover "the state". Of course, semioticians must be sceptical of Abrams' statement, "Social facts should not be treated as things." There is an important sense in which all things are social facts, and facts themselves are always socially constructed. ${ }^{6}$ However, this scepticism, together with Abrams' conclusion that "the state is not the reality which stands behind the mask of political practice [but] is itself the mask"17, sets the scene for a semiotic inquiry into /the state/ as a signifier, and the role the law plays in this semiotic arrangement.

In keeping with the suggestion that we may understand the state better through verbs than as a noun, one could look at the state's actions. It has ministries which collect and administer money, which build public infrastructure, which run educational and health programs and agencies. It has police who maintain order, assist in the administration of insurance by keeping records of property loss and damage, and bring suspected criminals before courts. These courts pass sentence and resolve disputes, administered by the state albeit 'at arms' length' (allowing for arms of different lengths in various jurisdictions). I have referred above to other, legislative, functions of the state.

It is clear from this description that there are innumerable different functions and functionaries making up 'the state'. Each of these manifestations exists in relative-or even explicit-isolation from the others. While they are brought together under the one signifier of 'the state' they are also divided by the 'separation of powers' into the various arms-executive, legislative and judicial-in a move which maintains the representational distance between 'law' and 'the state'. The state is thus at once represented as one entity and, like the Christian signifier the /Holy Trinity/, three entities in one. The symbolic architecture of the state points back to a certain unity. Flags, stories (of history or identity) and, above all, law frame the state as a representation of unity or power: a more or less convincing "claim to domination".

\footnotetext{
4 '[É]sa es la principal función del derecho: la creación del ente ficticio llamado estado.' Óscar Correas, Pluralismo Jurídico, Alternatividad y Derecho Indígena (Mexico DF: Fontamara, 2003), 61.

${ }^{5}$ Philip Abrams, "Notes on the Difficulty of Studying the State (1977)", Journal of Historical Sociology 1/1 (1981), 58-89 at 75, 77.

${ }^{6}$ The 'fact' was itself originally a legal fiction until science appropriated it from law in the seventeenth century. Barbara J. Shapiro, A Culture of Fact: England 1550 - 1720 (Ithaca: Cornell University Press, 2000), passim; Maria Bettetini, Figure di verità: La finzione nel Medioevo occidentale (Torino: Einaudi, 2004), 4-6; Yan Thomas, "Fictio Legis: L'empire de la fiction Romaine et ses limites médiévales", Droits 21 (1995), 17-63 at 17-18

${ }^{7}$ Supra n. 5 at 82
} 
This luxuriant proliferation of meanings ascribed to the one signifier /the state/ embodies that excess of signification over denotation which is characteristic of the floating signifier. The /state/ like the /separation of powers/ or the /Holy Trinity/ signifies so much that its specific denotations could never exhaust the possibilities: there will always be some remainder, some possible meaning which is not enacted. (Which never could be enacted because it is a mystery.) With this excess of langue over parole, the floating signifier means more than we can ever say, leaving the power of the signifier with force to spare. This goes a good way to explaining the mysterious semiotic power of /the state/ as a signifier.

What remains to be explained, however, is the process by which the legal fiction sustains this signifier in practice. To delve further into this semiotic puzzle, I intend to consider the contingencies of this process of legal constitution of the state. One can ask how law constructs the fiction of the state in its normal, efficacious operation. Another way to see how the legal fiction of the state works is to ask under what circumstances it does not work. I hope to shed more light on this process by asking under what circumstances this success may be challenged: are there ways in which law and its various semiotic manouevres fail to constitute a successful claim to dominance?

I have proposed that the successful constitution of the state as a legal fiction involves establishing it as a floating signifier, a sign with excess meanings that cannot all be spoken so that they overwhelm everyday semiosis with mysterious possibilities. This suggests that we might look for failures or 'misfires' 8 in constituting the state in the converse to the floating signifier: in everyday semiosis which gives its own meanings to the symbols of the state. If everyday life were thus able to speak its own meanings of state symbols, meanings which did not constitute the excesses of the floating signifier, but instead referred back to its own everyday activities, then it might subvert the semiotics which builds the legal fiction of the state.

This approach sets out to discover whether it is possible for a sign to mean less than it says. Can denotation overwhelm signification? In particular, is this possible in the case of those signs which constitute the legal fiction of the state? And, if it is, how does this affect the power of the state? If state power rests on the excessive signification of the floating signifier, then surely it cannot remain untouched if that signification is hollowed out, if the language of its legal constitution is overlaid with chatter and the everyday practice of communication. Such a signifier would not float on clouds of unexpressed meanings, dazzling us with its possibilities. Instead it would be submerged under excessive enactments of its meaning: we would express more than it could ever mean.

The question of law's effective constitution of the floating signifier of the state is both a pragmatic question for the political sociology of law, and a theoretical

\footnotetext{
${ }^{8}$ I use this term in the same sense and context as J. L. Austin did when applying it to failed performatives. J. L. Austin, How To Do Things With Words (Oxford: Oxford University Press, 1980) This is discussed further below.
} 
question for semiotics. If the floating signifier was the "guiding concept of the human sciences in the twentieth century", ${ }^{9}$ it is time to explore the possibility of exactly the opposite relationship between the sign and its meaning, through a reading of the quotidian reinterpretation of the legal signifiers of state power. I propose to consider these questions through some instances of the spatial semiotics of law and the state. I will show a number of ways in which spatial signifiers promote the state as a legal fiction, and I will also inquire into some others which are open to the risk of alternative constructions and interpretations.

\section{Spatial semiotics}

There are theoretical and methodological reasons for my choice of space as the site for this investigation. The process by which law constituted the state as the central force of symbiolic power was characterised, in western law and state development, by the increasing identification of law with space and place: the place of the crime, the uniformity of jurisdiction over a territory. "In brief, the competence delegated over a certain ressort (territory) replaced statutory precedence or authority exercised directly over persons." ${ }^{10}$ Weber also documented the increasing importance of lex terrae which relied on spatial, rather than personal, markers of jurisdiction. ${ }^{11}$ Fitzpatrick has posited that space, as an "existential imperative", is particularly well-suited to the role of grounding the law. ${ }^{12}$ Legal theory thus leads us to expect law and space to work together in the process of constituting the jurisdiction and, hence, the power of the modern state. $^{13}$

There are also important reasons to test the applicability of semiotic methods to the investigation of this relationship between law and space. That law is a particularly fertile field for semiotic analysis need hardly be argued in this journal. The conjunction between law, semiotics and space may require more introduction. ${ }^{14}$ In The Production of Space, Lefebvre explicitly takes issue with

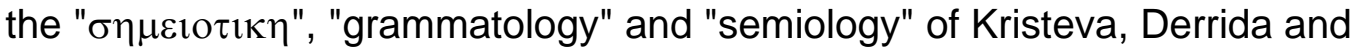
Barthes respectively. His general critique of all of these approaches is their elision of the connections between the social or physical world and that of mental concepts or language. This is expressed as the discovery of a theoretical "coupure or rupture of break" which for Lefebvre is no more than a lack of

\footnotetext{
${ }^{9}$ Giorgio Agamben, State of Exception, trans. Kevin Attell. (Chicago: University of Chicago Press, 2005), 37.

${ }^{10}$ Bourdieu sees the defining moment of this development in France in the ordinance of 1670 which centralised Royal power. Supra n. 2 at 49.

${ }^{11}$ Max Weber, Economy and Society. An Outline of Interpretive Sociology, trans. E. Fischoff et al. (Berkeley: University of California Press, 1978), 696-8.

12 Peter Fitzpatrick, Modernism and the Grounds of Law (Cambridge, UK: Cambridge University Press, 2001), 104.

${ }^{13}$ Seec also Richard Mohr, "Law and Identity in Spatial Contests", National Identities 5/1 (2003), 53-66.

${ }^{14}$ Denis Brion has explored these links in a number of papers, on issues as diverse as shopping centres, surface and mining rights in land, and the rights of landlords and tenants, collected in

Denis J. Brion, Pragmatism and Judicial Choice (New York: Peter Lang, 2003)
} 
philosophical attention to a whole area of social and physical relations: it "becomes the locus of a 'theoretical practice' which is separated from social practice". ${ }^{15}$

Lefebvre's materialist critique draws attention to the constitution of spatial semiotic codes at the level of practice, and not just of knowledge: "a spatial code is not simply a means of reading or interpreting space: rather it is a means of living in that space, of understanding it and of producing it". ${ }^{16}$ Barthes is criticised for neglecting the material on both "sides" of his analysis.

"On the near side, what is overlooked is the body. When "Ego" arrives in an unknown country or city, he first experiences it through every part of his body through his senses of smell and taste, as (provided he does not limit this by remaining in his car) through his legs and feet." ${ }^{17}$

Taken together with Lefebvre's emphasis on the production of space, this corporeal approach is particularly valuable as a guide to the present investigation. However, his analysis fails at the other "side" of his critique, where Lefebvre accuses Barthes of mistakenly trying to decode power. Lefebvre puts a whole area of theoretical analysis out of play: "For power has no code. The state has control of all existing codes ... and can shift from one to another at will. The state manipulates codes." ${ }^{18}$ The 'state' controlling codes, and shifting between them "at will" glosses over all the important ways that various elements of the state may construct spaces as signifiers, decode them and seek to specify the semiotic framework by which the citizens decode may them. Lefebvre's orthodox Marxist mistake of essentialising 'the state' is apparent in this towering noun, which even has a 'will'. ${ }^{19}$ This a priori rejection of any questioning of the semiotics of state power deprives Lefebvre's work of a vital element. Bourdieu's maxim is relevant here: "when it comes to the state, one never doubts enough". ${ }^{20}$ It is exactly the parameters and dialectical relationships of these codes which must be questioned in analysing the capacity and limits of law to constitute the state.

This inquiry takes up at the point where Lefebvre simply assumes that the state will be successful in controlling the semiotic regime. In the following pages I analyse examples of this success, which, as I have already proposed, rests on the excessive signification of state symbols. This excess of signification is attained, as I will show, with considerable effort, which is glossed over by Lefebvre's offhand attribution of will to the state in controlling and shifting between codes. I also seek situations in which codes shift according to interpretive processes which are not controlled by the state. The state is constituted in more contingent ways when everyday semiosis overtakes the

\footnotetext{
${ }^{15}$ Henri Lefebvre, The Production of Space, trans. D. Nicholson-Smith. (Oxford: Blackwell, 1991), 5-6.

${ }^{16}$ Suppra n. 15 at 47-48. This critique could be read as sympathetic to Peircean semiotics though it in fact derives from Marxian praxis rather than pragmatics.

${ }^{17}$ Supra n. 15 at 162.

18 Supra n. 15 at 162

${ }^{19}$ See my critique of this position above and Abrams' broader critique, supra n. 5.

${ }^{20}$ Supra n. 2 at 36.
} 
coding of the state, so that quotidian meanings build up around those symbols which only might imply state power. If they might also imply other meanings altogether, this would open up the possibility of a semiotic inversion of the excess meaning of the signifier. These alternative spatial and semiotic practices will help to discover whether the power constituting the state is determined by the langue of symbolic structures or is contingent on the parole of the everyday.

Bourdieu defines the state as the entity having the monopoly on symbolic power. The real president is distinguished from the madman who claims to be Napoleon by "the fact that he is recognized as founded to do so." ${ }^{21}$ That recognition is based in law. Law is "social magic that works". ${ }^{22}$ Magic is only convincing if it is done before our very eyes, nothing up the sleeves. For all the conceit of the lawyers that the force of law rests on the power of reason and the vigour of their arguments, the magic we are talking about here works through the body and space. $^{23}$

The present inquiry investigates interactions between law and space which illuminate ways in which law constitutes the signifier of state power. At the same time these interactions provide an opportunity to consider the overlay of alternative lived constructions, representations and interpretations of space and social relationships. I proceed by inquiring into the ways in which law and state power is represented spatially (by means of intentional building or naming projects) and how those codes are read, used and re-coded by the people who occupy those spaces.

In each case the references to law are literal: they include the orientation and location of courts and other vital state legal institutions, and the names of particular laws and law-makers which are chosen for places. I begin with the use of the axis as a signifier of power: this is found in courtrooms and projected out into cities. The axis is one of the most explicit and ubiquitous signifiers of power, from baroque Rome to Washington DC and the purpose built Australian capital, Canberra. With its linear and visual one-dimensionality, it both allocates responsibility and casts its representation of power over the city. My other study inquires into place names referring to laws and lawmakers: the ways they are changed or retained, decoded and re-coded. This study takes up the names of streets already considered as axes, and expands on those with examples from Mexico and Québec. Street names themselves are a manifestation of the symbolic power of law in constituting the state, so they offer a useful study of the capacity of symbols to retain their excessive powers of signification in the face of so much quotidian overlay.

${ }^{21}$ Supra n. 2 at 52.

22 Pierre Bourdieu, Language and Symbolic Power, trans. G. Raymond and M. Adamson. (Cambridge, UK: Polity Press, 1991) 42.

${ }_{23}$ ' $[I] \mathrm{n}$ order to fully understand the immediate submission that the state order elicits, it is necessary to break with the intellectualism of the neo-Kantian tradition to acknowledge that cognitive sttructures are not forms of consciousness but dispositions of the body.' Supra n. 2 at 54. 
In each case the signifier refers to law and more. Beyond the interpretability of a legal text, these floating signifiers speak of the sources of law and the possibilities of civic order. In exploring the extent and consequences of this excess of signification I will explore how legal power is projected out into the street. In the examples which follow this is effected, in the first place, spatially. By means of axes, symbols, and their very names, streets become conduits of legal power conjuring images of the state. But they are more than this: they are the space of everyday public life.

\section{Axes and alternative representations of power}

I begin from the originating place, the ground zero of law's power, the courtroom. Kelsen might maintain that law rests on the Grundnorm of the constitution, but $\mathrm{J}$. L. Austin knew how to do things with words, issuing from the mouth of someone in an authorised position. ${ }^{24}$ If we are going to take seriously the body which speaks with authority, we must also take seriously the position from which it speaks. Even if a person has been duly sworn as a judge, the opinions she expresses over dinner do not have the force of law: the judge must also be in an authorised place. The power of the law is projected from the bench where the judge sits. The bench has particular insignia symbolising the jurisdiction, that is, the judge's authority to give diction to the law (juris). This is often a flag, while in Australia and Canada the key symbol is usually a coat of arms. In Australia this object, usually in three dimensions or bas relief, is placed over the head of the judge, either on the wall behind or, particularly in older courts, on a canopy above. I have described elsewhere how these obscure signs, depicting heraldic devices of the British monarchy, lions, unicorns or Australian animals, can scarcely be decoded in the language of daily life. Even if we were to apply historical principles of heraldry we could still not know that this symbol denotes at once both the executive power of the state and the power of an independent judiciary. ${ }^{25}$ The mystery of the floating signifier is already apparent!

Now we have a full set of conditions for constituting the authority of the law. We have a judge, duly sworn and appropriately dressed. The judge is sitting in a proclaimed place ${ }^{26}$ in a dedicated building in a courtroom which is specific to the job of judging, on the bench, under the coat of arms or by a flag signifying the jurisdiction which authorises the judgement. We may next explore the space around this scene. So far the power of the state (through its symbols) has constituted the law, and together they have constituted judicial authority. Now we need to see how it is that judicial authority can order the world. This is how Geertz put it, in his discussion of the constitutive power of law:

\footnotetext{
${ }^{24}$ See, generally, Austin, supra n. 8 and Hans Kelsen, Pure Theory of Law (Reine Rechtslehre), trans. Max Knight. (Berkeley, CA: University of California Press, 1967).

${ }^{25}$ Richard Mohr, "Enduring Signs and Obscure Meanings: Contested Coats of Arms in Australian Jurisdictions", in Contemporary Issues of the Semiotics of Law, ed. Ann Wagner, Tracey Summerfield and Farid Benevides. (Oxford: Hart, 2005), 179-195) at 193-5.

26 'The Governor may, by proclamation, specify places at which the Court may sit, and one of those places shall be Sydney.' District Court Act (NSW) 1973, S 18. F (1) .
} 
Law, even so technocratized a variety as our own, is, in a word, ... constitutive .... A notion, however derived, that adjudication consists in a willed disciplining of wills, a dutiful systematization of duties, or an harmonious harmonizing of behaviors ... contributes to a definition of a style of social existence... ${ }^{27}$

How does adjudication do this? How does it escape the courtroom, in order to discipline, to order and to re-constitute the power of the state, thus re-constituting the judicial power itself? Just how does it define social existence?

Let's take a closer look at the courtroom itself, in order to see some of the spatial elements which are used to project power. In Australia the coat of arms and the judge are generally in the centre of the court. The representatives at the bar table are equidistant from the judge, representing the even-handedness of the court. They are placed on either side of an axis which runs from the centre of the bench, where the judge is seated, through the middle of the courtroom and usually faces the public door into the courtroom. We may follow this axis out the door of the courtroom, into the street. I will deal shortly with some expressions of the continuity of these axes from the courtroom into the urban fabric. Of particular legal interest is the axis running from the centre of the bench of the Supreme Court of the United States in Washington to the centre of the Capitol building. But first let us discover what we can of the rationale and history of this powerful urban form.

The axis is an important and ubiquitous signifier of power in town planning. First used in the sixteenth century for representational more than functional purposes, the axis became an indispensable symbol (and at times a vehicle) of state power in national capitals from sixteenth century Rome to twentieth century Canberra. In the Rome of Sixtus V (1585-90) elaborate projects were designed, carried out or projected, which would inscribe a cross in the centre of Rome; a star symbolising the virgin Mary, health, Christ and the Pope himself; and the layout of the basilicas as the constellations Ursa Major and Ursa Minor (the latter representing Saint Peter's basilica at the pole star). These projects were realised as streets (the cross), or partly realised with obelisks and vistas (the star), or were conceptual depictions (the constellations). Together they layed a representational framework over the city which stamped it with the "immense authority of the Pope". ${ }^{28}$

This elaborate and decidedly pre-modern scheme for representing authority through streets, monuments, sight lines and imaginary plans reflecting the heavens is replete with floating signifiers. It can be seen to have influenced the next four hundred years of planning capital cities. The best known examples of axes in town planning occur in the great capitals of the classical period of the

\footnotetext{
${ }^{27}$ Clifford Geertz, Local Knowledge: Further Essays in Interpretive Anthropology (New York: Basic Books, 1983), 218.

${ }^{28}$ Maria Luisa Madonna (ed), Roma di Sisto V: Arte, architettura e città fra Rinascimento e Barocco (Roma: Edizioni De Luca, 1993) 20-23
} 
consolidation of centralised state power: just that period when law's ambit was becoming marked by space rather than personal characteristics.

The axis is a line of sight. Lines of sight work both ways. While we look up to the judge in the centre of the courtroom, the judge has a clear line of sight down from the bench. Axes allow a clear view of the city, an assessment of the state of discipline in town. David Hockney has pointed to the contemporaneous development of perspective and artillery: "a line of sight can also be a line of fire". ${ }^{29}$ The opening up of the boulevards in Paris or the Ringstrasse in Vienna offered a clear shot and a direct route from the barracks to the workers' districts. This was the "strategic basis for the perspectival articulation" of Paris. ${ }^{30}$ Military forces can shoot and march troops down the boulevards. They can also see down them. Yet even the movement of troops was used to signify as much as to wield power.

"The aesthetic effect of the regular ranks and the straight line of soldiers is increased by the regularity of the avenue: the unswerving line of march greatly contributes to the display of power, and a regiment moving thus gives the impression that it would break through a solid wall without losing a beat. That, of course, is exactly the belief that the soldier and the Prince desire to inculcate in the populace: it helps keep them in order without coming to an actual trial of strength, which always carries the bare possibility that the army might be worsted."

That the role of the axis as a trope of the capital city both predated and outlasted its strategic importance for the movement of troops emphasises its representational significance. It is a remarkably durable form. Mumford refers to those urban plans based on avenues, vistas and the projections of power as "baroque", rather stretching the historical reference of the word to encompass the fourteenth century arcades of Florence and L'Enfant's 1791 plan of Washington DC. He runs into political as well as temporal problems with this categorisation since he also associates the baroque with absolutist monarchical regimes, an uncomfortable fit with the capital of the new American republic. Extending the frame of reference even further, to twentieth century Australia, we find that avenues, vistas-in short, axes-are particularly explicit in the town planning of Canberra.

Initially planned by the team of the Griffins, and implemented since the 1920 s by the National Capital Development Commission, Canberra is as alive with axes as any baroque city. The Federal Courts face an axis which begins with University Avenue and becomes the minor axis of Constitution Avenue. We see the Parliament from all directions, framed by the city to either side of the roads. We look up to it, on its hill. By placing a symbolic building at the vanishing point the

\footnotetext{
${ }^{29}$ Quoted in Peter Jukes, A Shout in the Street: The Modern City (London: Faber \& Faber, 1990), 104-5.

${ }^{30}$ Walter Benjamin, The Arcades Project, trans. H. Eiland and K. McLaughlin. (Cambridge, MA: Bellknap Press of Harvard University Press, 2002), 121.

${ }^{31}$ Lewis Mumford, The City in History: Its Origins, Its Transformations and its Prospects (Harmondsworth: Penguin, 1966) 423
} 
planners focus attention on the Parliament, emphasising its preeminent power. It is at the focal point of the two traffic streets of Commonwealth Avenue and Kings Avenue, coming in from the business district and from the Department of Defence, crouched behind the 73 metre high American eagle which commemorates the US-Australia defence alliance. ${ }^{32}$ The War Memorial is on a central axis, free of cars. In the intention of the planners and the government this is a pedestrian space, devoted to people and plants and interrupted only by the old Parliament House. ${ }^{33}$

The axis between the Capitol and the Supreme Court in Washington is more like a mutual salute than a defensive strategy. The axis of the Supreme Court faces the towering Capitol in a gesture of fidelity. Facing back the other way we may walk from the direction of the Capitol up the steps of the Supreme Court and down the length of the Great Hall through the public door into the courtroom, where its curved back wall reflects the power of the bench back onto us like the parabola of a satellite dish. This is where blame is allocated. The buck stops here.

Outside the cars move up and down Constitution Avenue, which borders the parklands in which the Capitol and the Washington Monument are set. Westbound traffic passes between the Monument and the White House lawns. Eastbound traffic quickly disgorges into the poor Afro-American districts with security grilles or bullet-proof glass on every window, even those through which commerce must be done: buying petrol or fried chicken. The stately flow of the cars does nothing to unsettle the fiction of the state. The legislative traffic flows down Constitution Avenue between the lawns of the White House and the Capitol, the Capitol and the Court. From this tourist's eye view of Washington, we can see the Grundnorm, and it works. No problem here for the constitutive theory of law, for the judges, town planners or presidents.

Space is a medium for signs: what can it signify? Washington represents the separation of powers in the placement and the built form of the government buildings and the naming of Constitution Avenue. As I said in introducing this study, representations of the separation of powers exude an excess of signification. They invite us to interpret them in so many ways that we cannot count them, or even express them all. From this they derive their power. However, the space of the city is more than a theme park of state power: it is the theatre of our everyday life. Urban spaces, particularly streets, also have meanings that are expressed by pedestrians, the people who use the street.

\footnotetext{
32 'Opened by Her Majesty the Queen on 16 February 1954, [the monument] expresses the deep gratitude felt by Australians to American service personnel for their assistance to Australia during the War in the Pacific from 1941-1945.' Robert Hill, Minister for Defence, Media Release (27/2004): $50^{\text {th }}$ Anniversary of Australian-American Memorial, 16 February 2004. As the Minister makes clear, the monument and its commemoration still have semiotic work to do in invoking history and the alliance in support of Australian and US armed forces 'working side by side around the globe and in our own region - in East Timor, Afghanistan and Iraq.'

${ }^{33}$ I will return shortly to discuss the indeterminacies of meaning introduced by people: 'pedestrians', in the language of the planners.
} 
These subversive interpretations may be explicit, in the form of protests.

Demonstrators are often seen beyond the White House lawns. The central axis to Canberra's Parliament House has, for more than thirty years, been occupied by the Aboriginal Tent Embassy. ${ }^{34}$ These protests explicitly address the semiotics of the capital. They face the White House, or interrupt an axis of power. They indicate the potential for alternative meaning-making within the context of an existing signifier. The choice of space in which these protects take place seems to recognise the dominance of their power. By adding yet another interpretation to the floating signifiers of state power, they emphasise their excess of signification, even as they interrupt their channels of power.

The Aboriginal protest interrupts the main axis signifying the power of the Parliament of Australia with an inhabited camp which recalls a way of life which preceded British colonisation. The Tent Embassy is thus a permanent reminder of prior occupancy of the land and the prior claims of an alternative legal system. Demonstrations at the White House may reinforce the legitimacy of the legal system which they recognise by their presence, but the Tent Embassy juxtaposes Aboriginal sovereignty to that of the Commonwealth. While the plan and the vistas of Canberra recall the legal process by which the state is constituted, their interruption by a living reminder of a competing source of law threatens to throw the astrology of state power off its axis.

\section{Naming and commemoration}

Up to this point I have focused on the spaces around courts and on those spaces which concentrate representations of the formal power of the state. In national capitals, I referred to streets bearing names representing legal instruments and forms: Constitution Avenue, Commonwealth Avenue. These names are part of the self conscious meaning-making of politicians and others who are in a position to wield this power of coding and commemoration.

Gramsci identified street names as part of the material ideological structure of the dominant class which is "intended to maintain, to defend and to develop the theoretical and ideological 'front'." He could only dream in a fascist prison of chronicling all those devices, which would include the media and the associations of civil society, "right through to architecture and the layout of streets and their

\footnotetext{
${ }^{34}$ I have discussed the Tent Embassy in the context of alternative interpretations of the coat of arms based on alternative interpretants (supra n. 25). Since writing that analysis I have seen a documentary film in which the Yolngu Aboriginal people of Northern Australia see the use of local animals (which represent their moieties) as giving the Australian law more, not less, legitimacy. It was not 'another law but it was the law for Australia.' (Tom Murray. Dhakiyarr vs the King. Lindfield, NSW: Film Australia, 2004) When I sought permission from them to use this clip from the film for teaching purposes, the Yolngu representatives explicitly asked me not to confuse their position with that of the Tent Embassy. This illustrates the power of the coat of arms as a floating signifier. The more interpretations it can be given, the more power it has.
} 
names". ${ }^{35}$ We gain some more insight into the practical application of such a strategy from the comments of the mayor of Rome on the commemoration of the sixtieth anniversary of the defeat of fascism. Concerned at recent manifestations of "the historical and political forgetting that can lead a boy to fly a fascist flag in the football stadium", Mayor Veltroni proposed to encourage a more acute memory of events of the 1940 s by renaming a school and an avenue in a park after students who were killed by "the Nazi madness". ${ }^{36}$

Street names are an intricate part of memory. One of the first things we must commit to memory as children is the name of the street we live in, and throughout life we orientate ourselves by the names of the streets we visit, travel through, live and work in. Street names are the link between the abstraction of the map and the mnemonic of narrative. ${ }^{37}$ They weave in and out of the narrative of our lives, whether as a memorised itinerary or a succession of homes and haunts. Can politicians or city officials re-code these memories into forms which will promote allegiance to a class (as Gramsci suggested) or to a belief in the state as a concrete product of legal fictions?

Street names have more relevance and hence more specific reference as signifiers in some contexts than others. I have already referred to the semiotic lock-step of vehicular and legislative traffic on Washington's Constitution Avenue. I would like now to turn to more explicit examples of the ways in which the meaning-making of everyday life may overlay, and perhaps ultimately submerge, the signifiers of state power. To discover more about the relationship between intended meaning and day-to-day decoding I will consider some street names in more intensely lived-in spaces than the Constitution Avenues I have considered.

Mexico City, Distrito Fedéral, in a style which is familiar from my other Federal districts examples (DC, ACT), also has streets named for the founding law of the republic, the Constitution of 1917 . The Plaza de la Constitución lies between the Supreme Court and the Cathedral, which itself is practically built over an important Mayan temple. The palimpsest of tradition runs deep in this ancient city. The official name of the plaza is never used by the people, who call it the Zócalo. A few blocks away from this ceremonial centre of power, with its interplay of references to law, state, church and ancient culture, is another street named after the Constitution of 1917 . This street modestly refers only to one article of the Constitution: it is Calle Artículo 123.

\footnotetext{
${ }^{35}$ Gramsci conveys his yearning for such a dream: 'quanti bellissimi capocronaca si potrebbero scivere sull'argomento!' Antonio Gramsci, Quaderni del carcere (Torino: Einaudi, 1975) vol 1, 332-3.

${ }^{36}$ Beatrice Rutiloni, “'La memoria non dura un giorno.' Cortei e musica per il 25 Aprile”, La Repubblica, 21 April 2005, Cronaca di Roma iv. Of course, Rome already has a 'via Antonio Gramsci'.

${ }^{37}$ De Certeau traces the origins of maps out of itineraries, noting the generalising (scientific) purpose of maps compared with the narrative of itineraries. Michel de Certeau, The Practice of Everyday Life, trans. Steven F. Rendall. (Berkeley, CA: University of California Press, 1984), 11822
} 
Article 123 confers the right to dignified and socially useful work, while subsections prohibit child labour and refer to the eight hour day and other workers' rights. This is a busy street but it not a ceremonial thoroughfare. There is no critical connection between major national institutions, no impressive vista. It is a work-a-day street, commemorating the right to work. Article 123 is also represented in a Diego Rivera mural in the Palacio Nacional. It was clearly a matter of pride that the Mexican Constitution had such a provision, and worth reminding workers and others that this right existed. In naming a street for an article of the Constitution I am suggesting, then, that it may have mnemonic and commemorative value. It may reinforce the allegiance of workers to the Constitution while raising awareness of a right which is notoriously difficult to enforce. It may have been more effective to have called the street Calle Derecho al Trabajo ('Right to Work Street'), but that would only have recalled an unrealised right, not the national Constitution.

The state's intentions in naming streets can be subverted by popular usage, as in the use of 'Zócalo' instead of 'Plaza de la Constitución'. It can also be contested by competing conceptions of the state and the nation. We see this in name changes which follow regime change: St Petersburg to Leningrad and back again. To the words of the old song about Istanbul,

"Why Constantinople got the works

is nobodies' business but the Turks"

it should be added that some Greeks may have had a different view.

My last example of street names comes from Québec. Major streets in Montréal and Québec City are named Boulevarde René-Lévesque for the founder of the Mouvement souveraineté-association (MSA) in 1967, President of the Parti québécois, and Premier (Premier ministre) of Québec 1976-85. ${ }^{38}$ These streets were re-named after Lévesque died in 1987. Streets, like cities, must lose a name in order to gain a new one. Will anyone object, or care about the old name? ${ }^{39}$ In Québec City, prior to 1988 Boulevarde René-Lévesque was Boulevarde St-Cyrille. It was changed only a few years after the 1985 Papal Encyclical Slavorum Apostoli on the $11^{\text {th }}$ centenary of Saints Cyril \& Methodius. Whatever the Catholic Church's view on this apparent slight, it did not have the power or the will to oppose it.

In Montréal, the name that was lost came from that other target of Québec's 'quiet revolution': anglophone hegemony. ${ }^{40}$ The Montréal street was previously named Dorchester Boulevard, after an $18^{\text {th }}$ century British Governor of Québec and Governor-General of Canada, who had been wounded fighting the French in

\footnotetext{
38 Assemblée Nationale de Québec http://www.assnat.qc.ca/fra/membres/notices//-1/lever.htm accessed 6 April 2005.

39 The rejection of an old name may be even more important than the adoption of a new one, as in the case of Piazzale Adolfo Hitler in Rome, changed to Piazzale dei Partigiani.

40 'La révolution tranquille' refers to the transformation of Québec in the 1960-70s which saw a simultaneous decline in the ideological influence of the Catholic Church and the political influence of the English-speaking population. Of course, René Lévesque was a key figure in that 'revolution'.
} 
the battle of the Plains of Abraham. However, the English-speaking population had more temporal power in this situation than did the Church in Québec. The boulevard runs from the local government jurisdiction of the City of Montréal (arrondisement Ville-Marie) into that of Westmount, dominated by English speakers, who refused the name change. Boulevarde René-Lévesque only runs as far as the border with Westmount, at Atwater, where it reverts to the name of Dorchester. At this corner I found that Anglophone intransigence had apparently upset someone enough that they deformed the 'Dorchester' sign, without managing to remove it altogether. Street names, as mentioned above, are commemorations: Lévesque could only be remembered after his death, while this entailed the concrete (or attempted) forgetting of St Cyril and Dorchester.

This example from Québec highlights a key point about the signification of street names in the semiotic project of constructing /the state/ as a product of law. As well as commemorating the law itself, as in names like Constitution Avenue or Artículo 123, street names may commemorate particular law-makers. To choose a Québécois law-maker like Lévesque over an English one is to commemorate a preference for a source of law. The very suggestion that we may choose the source of law is perhaps the most subversive semiotic act of all, when it comes to the legal constitution of the state. The state loses the determinacy of its "claim to domination" which then becomes contingent on political choice. ${ }^{41}$ The street with two names, René-Lévesque and Dorchester, while commemorating two conflicting sources of law also commemorates the very contingency of the law itself in constituting the state.

But what's in a name? The streets in the heart of a busy city are used by cars, pedestrians, people making deliveries, doing business and socialising. They bring life to the streets, which are a part of their own lives. This space is made by the people who use it, who live it. It is the sort of space that de Certeau has in mind when he writes, "In short, space is a practiced place. Thus the street geometrically defined by urban planning is transformed into a space by walkers."

While street names may commemorate laws or law makers they are also part of our day-to-day discourse. They become directions, daily routes or special excursions, addresses, memories and mental maps. Street names are etched into our memory in a process which involves active coding of our own narratives, habits and itineraries as well as our use of the material that is provided, by way of the physical layout of the streets and their names. Those who give the streets their names are also working at the level of memory, encouraging us to recall particular legal foundations of the state, sources of law and other signifiers of legitimacy. These codings of personal and official memory become entwined, particularly in busy city streets, so that addresses, activities and memories of

\footnotetext{
${ }^{41}$ Abrams, having noted that the state 'never emerges except as a claim to domination' (see above), observes that this claim is most effectively challenged not by political theorists, whether Marxist or conservative, but in the 'specific exigency created when individual revolutionaries find themselves on trial for subversion, sedition or treason.' Supra n. 5 at 77.

${ }^{42}$ Supra n. 37 at 117.
} 
Boulevarde René-Lévesque or Calle Artículo 123 overtake the original significance of the names themselves. The Zócalo in Mexico City is an instance of popular memory dominating the official naming of the plaza after the Constitution: the density of the narratives of daily life in that place could not be recoded in line with official memory. The official narratives are more capable of dominating in the Constitution Avenues of Washington or Canberra, with their parklands and traffic. To borrow from David Byrne's song, the "Heaven" of planners and advocates of the state "is a place where nothing ever happens". ${ }^{43}$ Where there is so much happening, as in downtown Montréal or Mexico City, the density of daily life, memory and meaning submerges the official meaningmaking.

\section{Re-coding law's spaces}

In these investigations of legal referents in the layout, use and naming of streets I set out to discover some of the possible processes by which the legal fiction of the state is in a permanent state of renewal. I proposed, in introducing this article, that for the state to continue to function as an effective floating signifier it would need to be continually constructed: it did not spring into being, once and for all, with the Royal ordinance of 1670 or the Act of Settlement of 1701 . The strenuous efforts of constitutional courts and legal discourse to maintain the fictio legis of the state can be seen in any number of legal texts. Rather than analysing such texts I have tried here to understand the relationship between law and the constitution of the state by seeing how this may work at the level of practice through the social and material medium of space.

Those instances where the state was found to be most definitively coded as a legal fiction-a unified entity subject to the rule of law-occur in purpose built capitals, dedicated to the business of the state. The baroque practices of coding narratives of the signifiers of power and authority into urban axes continue to serve the descendents of those early centralised states conjured by law. Exclusive jurisdiction over space is signified in in the heart of the capital by vistas and avenues which tell us of the separation of powers, the supremacy of parliament and the rule of law founded on a constitution.

In cities where people go about their everyday activities, place names may commemorate particular law-makers or other sources of law. As the etymology of that word suggests, we remember laws or law-makers together with addresses, itineraries and the narratives and mental maps which make sense of our lives. On that terrain lawmakers and other political groups compete to interweave their signifiers of the sources of law into these constructions of memory. In cases where there is little contestation of the sources of law these commemorations are enacted and overlaid with little conscious attention to the state's legal foundations (of which more below). However, I have remarked on instances, in Australia and Canada, where the smooth coding of a monolithic legal foundation for the state

${ }^{43}$ Daviid Byrne, Heaven (Index/Bleu Disque, Sire Records 1979). 
has been interrupted by Aboriginal and Québécois sovereignty claims. The memory of alternative sources of law challenges any state that rests its claims to domination on a homogeneous legal order. But to recognise the overlays of contingent memory is essential to an understanding of our coding and de-coding of urban space. Far from there being two competing orders, 'one of which must be right', there is no order other than that which we inscribe in our everyday practice of social space.

Spaces in the centre of purpose-built capitals may bear an excess of signification, referring to the always-already but never-enough magic of the state. Yet city streets are so intensively used, spoken and re-represented that they can come to mean more than their names. Spaces and even buildings, as sites of human activity, participate in their own interpretation, recreating their hermeneutic framework day by day and hour by hour.

Where law must be interpreted through texts, the appeal to a unique founding text or a structure of positive law is always possible. Though the interpretation may be indeterminate, the signifier is clear. But in the interplay of law and space we find the codes being inscribed and re-inscribed, in city streets, in itineraries, in personal and collective narratives. Every interpretation is a re-coding. Law may be represented as a determinate code, but as soon as it is inscribed on the city it is already overcome by new interpretations and re-codings.

When law becomes part of lived experience, the subjects, no longer a fictional construct of law, reinscribe the law in naming their own spaces and narratives and in mutual interpetation of eachothers' actions. In the production of space, as soon as Lefebvre's or Barthes' 'Ego' gets out of the car and into the street, feeling the texture of the pavement, the chill in the air, the humidity and the smells, she or he is participating and acting in an environment. Beyond Agamben's observation that without language there is no experience, ${ }^{44}$ we might add that there is no interpretation before experience. We interpret the claims of law using the interpretive frameworks within which they are located, including our own narratives and life experiences.

I noted, in introducing this study, Lefebvre's criticism of Barthes' attempt to decode power, which "has no code ... only strategies". He went on to say that the state could shift between codes at will. I have tried here to analyse this "dualism that opposes meaning to material reality" as one of the strategies of power, and to assess its successes and limitations. ${ }^{45}$ The significations of the state, constituted as a legal fiction, are always indeterminate. As a floating signifier, the state can indeed always mean more than is stated. The official spaces of national capitals can conjure the fictitious entity of the state which changes, seemingly "at will", between a unity, a trinity and a hydra-headed monster. But as we move away from the spaces designed to invoke the power of the nation state into more

\footnotetext{
${ }^{44}$ Giorgio Agamben, Infanzia e storia: Distruzione dell'esperienza e origine della storia (Torino: Einaudi, 2001), 44ff.

45 Timothy Mitchell, "Everyday Metaphors of Power", Theory and Society 19/5 (1990), 545-577 at 546.
} 
anarchic spaces, places of work and commerce, law and the social order may be constituted differently. The meanings of the state are also indeterminate because its significations are de-coded and re-coded in an endless process of action and experience. Far from experiencing a duality between the material and the semiotic in everyday life, we code places, actions and memories into narratives and desires. Deprived of its transcedent semiotic possibilities by everyday life, the floating signifier can be weighed down, and finally submerged, under our constant communication. The inhabitants of cities say more than the signifier can ever mean. 